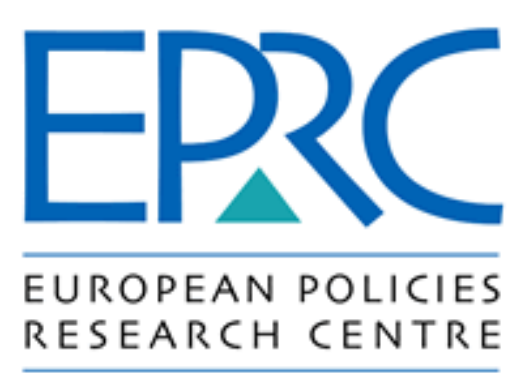

\title{
The Small Projects Fund and Social Capital Formation in the Polish-German Border Region: An Initial Appraisal
}

\section{Katja Mirwaldt}

\author{
July 2009 \\ European Policy Research Paper
}

Number 68

Published by:

European Policies Research Centre

University of Strathclyde

40 George Street

Glasgow G1 1QE

United Kingdom

ISBN: 1-871130-74-3 


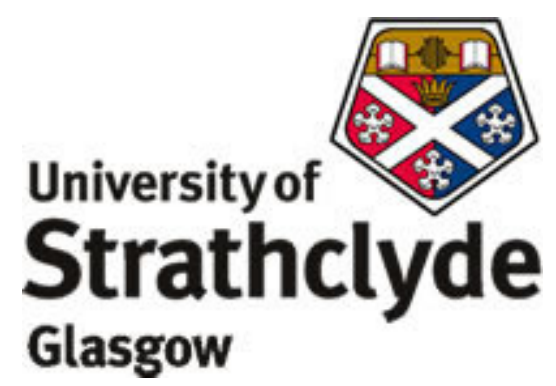

\section{European Policies Research Centre \\ University of Strathclyde \\ 40 George Street \\ Glasgow G1 1QE}

Tel: +44141548 3339

Fax: +441415484898

Author email:

katja.mirwaldt@strath.ac.uk

www.eprc.strath.ac.uk/eprc

The University of Strathclyde is a charitable body, registered in Scotland, number SC015263. 


\section{Preface}

This paper examines the small projects fund, an EU-funded initiative to promote good citizen relations across borders. The paper presents this fund as an attempt to foster 'social capital', that is social trust and citizen networks, in the Polish-German border region. The fund is examined in the light of seven conditions of social capital formation. In the PolishGerman border region, the fund scores well on the first four conditions that are related to the promotion of individual trust. It performs less well on the three conditions for scaling up individual trust to form social capital. However, it remains to be seen whether small project support can deliver improved citizen relations. 
The Small Projects Fund and Social Capital Formation in the Polish-German Border Region: An Initial Appraisal 


\section{CONTENTS}

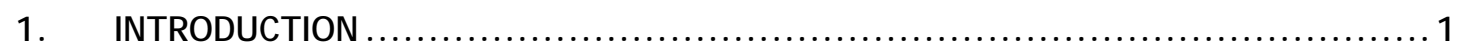

2. SOCIAL CAPITAL: MEANINGS, ORIGINS AND PREREQUISITES....................... 2

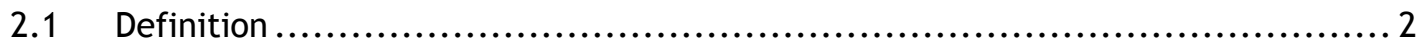

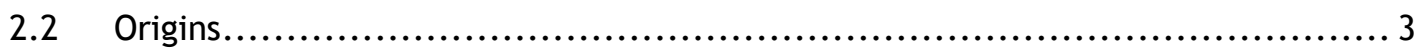

2.3 Preconditions of social capital formation .................................. 4

3. BORDER REGIONS' SPECIAL NEED FOR SOCIAL CAPITAL: THE POLISH-GERMAN CASE

4. THE SMALL PROJ ECTS FUND IN THE POLISH-GERMAN BORDER REGION $\ldots \ldots \ldots \ldots \ldots 8$

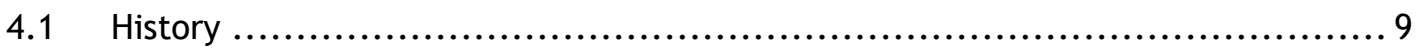

4.2 Management and implementation .............................................. 9

4.3 The projects: numbers, cost and content .................................... 10

5. CONDITIONS OF SOCIAL CAPITAL FORMATION IN THE POLISH-GERMAN BORDER

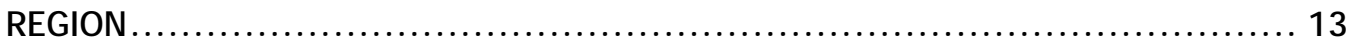

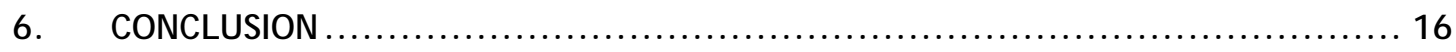

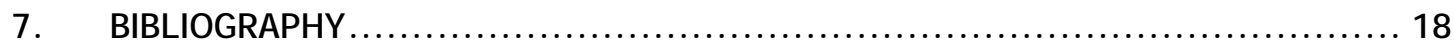


The Small Projects Fund and Social Capital Formation in the Polish-German Border Region: An Initial Appraisal 


\section{The Small Projects Fund and Social Capital Formation in the Polish-German Border Region: An Initial Appraisal}

\section{INTRODUCTION}

The aim of this paper is to examine the link between cross-border policy-making on the one hand and citizen relations across the border on the other. Using the Polish-German border region as an example, the paper examines the so-called 'small projects fund'. This is an EU-funded policy initiative that is aimed specifically at bringing people together in order to improve citizen relations across borders.

Academic interest in border regions has flourished in the past two decades. Borders in Europe have received particular attention because they tend to be unusually open to crossborder traffic of goods or people (O'Dowd, 2002; Anderson, 1996). Moreover, in Western Europe, there have been special efforts to promote cooperation between border regions and municipalities since the 1950s. Similar efforts have recently also been transferred to the Central and East European borders (Perkmann, 2003). These schemes are particularly important here. Unlike many West European borderlands, Central and East European border regions often do not benefit from any unbroken centuries-old links. Borders in this part of Europe typically look back on a recent history of violence, expulsion and walling-off (Batt and Wolczuk, 2002).

A lot of the empirical research has focussed on cross-border governance and policy (Blatter, 1997; Perkmann, 1999; Scott, 2002; Kepka, 2004). Other researchers have examined relations among border populations (Lisiecki, 1995; Zich, 1998; Szabo and Koncz, 2006). Usually, however, policy-making and social relations are treated separately, as if policy had no impact on border populations and the local setting did not shape regional networks. ${ }^{1}$ Where there have been analyses of policy attempts to bring people together, such as the small projects fund, research has all too often consisted of mere assumptions about the beneficial effect of cross-border cooperation or of reasoning by analogy with Western European cases (Grix and Knowles, 2002; Yoder, 2003; Kennard, 2004).

This paper develops a more rigorous way of assessing the impact of cross-border policymaking on citizen relations through a study of the small projects fund. It elaborates seven tests of potential policy impacts. This is done by employing the concept of social capital, in other words a combination of trust and cooperative networks among those living on the borders, the 'borderlanders'. The paper shows that there are some preconditions for the development of social capital that can be used to assess actual cooperation experiences. The focus is on the Polish-German border region. With its attempts to overcome past conflicts and generate social capital, this region is representative of the challenges that Central and East European border regions face.

\footnotetext{
${ }^{1}$ Some laudable examples to the contrary include Strüver (2004) and Häkli (2004).
} 
The analysis is based on documentary evidence and on semi-structured interviews with border regional policy-makers. The documentary evidence includes guidelines issued by the European Commission, Euroregional publications and evaluations of the cross-border programmes. As for the interviews, most interviewees were representatives of the so-called Euroregions, that is to say those organisations that implement the small projects fund. Interviewees also included regional policy-makers who are in charge of coordinating crossborder cooperation. Sixteen interviews were conducted in two waves: nine interviews in 2005 and seven in 2009. Interviews covered the detailed workings of the fund as well as policy-makers' assessments of its failures and successes. To safeguard confidentiality, these interviews are referenced numerically here, indicating whether they were conducted with a Pole (PL) or a German (DE) interviewee.

This paper is structured as follows. The next section introduces the concept of social capital. It shows how social capital comes about and derives seven conditions for social capital formation from the literature. The third section introduces the case study. Using the example of the Polish-German border region, it demonstrates why social capital is particularly important in border regions, particularly in Central and Eastern Europe. The fourth section describes the origins of the small projects fund, how it is implemented, and what it has achieved at the Polish-German border. The fifth section tests the small projects fund against the seven conditions of social capital formation, showing that the fund satisfies the first four conditions that are related to the promotion of individual trust, while performing less well on the three conditions for scaling up individual trust to form social capital. The paper concludes by highlighting some implications for further research.

\section{SOCIAL CAPITAL: MEANINGS, ORIGINS AND PREREQUISITES}

Social capital, though academically fashionable, is a controversial concept. It has received a great deal of attention throughout the 1990s and 2000s but remains nebulous and illdefined (Durlauf, 1999; Fine, 1999). Often, the application of social capital raises more questions than it answers. For example, it is not clear which indicators are suitable to measure social capital, whether it should be used as an independent or as a dependent variable, and how benign a phenomenon it is.

Social capital is nonetheless used here as an analytical tool because it is suited to evaluating the policy initiative in question. As Section 2 will show, the rationale of the small projects fund, regarding the economic and policy implications of citizen relations, bears a strong resemblance to social capital. In this context, the main theoretical question is whether and how social capital can be stimulated. The fund is measured against the criteria set out in the social capital literature, while bearing in mind the shortcomings of this literature.

\subsection{Definition}

The term 'social capital' is used to denote networks and trust relationships between different people. As the word 'capital' indicates, it is often seen as a valuable property which facilitates social, political and economic life. Social capital is sometimes perceived 
as the individual ability to achieve one's particular ends (e.g. Coleman, 1988). Other social scientists go beyond this individualistic definition. For example, Robert Putnam, in his famous Bowling alone, describes networks and trust as public goods:

'A society characterized by generalized reciprocity is more efficient than a distrustful society, for the same reason that money is more efficient than barter. If we don't have to balance every exchange instantly, we can get a lot more accomplished. Trustworthiness lubricates social life.' (Putnam, 2000: 21)

Trust is seen as confidence in other people's dependability (Levi, 1998). In high-trust environments, transaction costs for such diverse areas as education policy, democratic processes or economic productivity are said to be noticeably lower than they are in lowtrust societies (Putnam et al, 1993; Fukuyama, 1995; Whiteley, 2000). Thus, social capital has important normative implications. However, it can also have negative consequences, as illicit organisations such as the mafia benefit from social capital. Within certain groups, it can lead to the exclusion of outsiders (Durlauf, 1999). In this context, Putnam has put forward an important distinction between the type of social capital that is usually seen as beneficial and the type that might lead to negative outcomes. The former takes the shape of inclusive relationships that bridge the gap between different groups. Examples include cooperative undertakings such as ecumenical organisations or attempts to promote international understanding. Putnam refers to this as 'bridging social capital' (Putnam, 2000: 22) which can be defined as trust and networks between members of different groups, such as religious groups or nations. Conversely, 'bonding social capital' is oriented towards group cohesiveness and tends to be more exclusive and inward-looking. Examples include the trust relationships within nationalist groups or clans. These groups seem more likely to exclude and even reject others (Portes, 1998).

A feedback loop is clearly implied in either notion of social capital: if trust reduces transaction costs and if lower transaction costs in turn justify trust and increased interaction, then society is experiencing a virtuous circle (Putnam et al, 1993). Similarly, if a lack of trust prevents any effective solutions to social and policy problems, the stalemate would tend to be self-perpetuating. This may capture something of the self-reinforcing nature of social capital. However, it obscures the relationship between the dependent and independent variables. Thus, Putnam claims that social capital increases efficacy, in government or economic development, but it seems equally plausible that efficient government or economic development inspire social capital (Levi, 1996; Foley and Edwards, 1999; Uslaner, 2003). For the analyst, it is important to draw a clear distinction between the causes and the consequences of social capital (Portes, 1998).

\subsection{Origins}

The question of how social capital comes about in the first place has so far been answered only partially. Francis Fukuyama (1995) argues that trust is culturally determined and cites various historical reasons to explain variation between different contexts. Still, he does not reflect on the origin of these differences. It has been suggested that cooperative initiatives emerge spontaneously and that they are self-reinforcing in most circumstances. However, certain negative conditions may prevent the growth of social capital (Boix and Posner, 
1998). Potential obstacles include a high degree of inequality as well as weak law and order (see also Woolcock, 1998 and Uslaner, 2003). The interesting question, then, 'is not why cooperation exists but rather why it does not' (Boix and Posner, 1998: 688).

There is an evident policy relevance to the question of where social capital comes from. If it is true that social capital brings social benefits, then there is a strong incentive to look for ways to foster social capital. For example, successive World Development Reports describe social capital as part of the solution to poverty (Fine, 1999). Similarly, there are attempts to build bridging social capital in the border regions of Central and Eastern Europe, where there is little history of cross-border cooperation.

Putnam (2000: 21) has suggested that 'frequent interaction among a diverse set of people' brings about social trust: through interaction, people get to know each other and familiarity generates trust. Social capital, too, is said to be determined by:

'...the extent to which individuals have regular contact with others, beyond the sphere of the family or the market, and notably the kind of face-to-face relations of relative equality associated with participation in common endeavours, whether recreational, social, service-oriented or political.' (Hall, 1999: 418).

While contact may bring about social capital, it is less certain whether public-sector intervention can initiate social capital formation by fostering such contact. If social capital is seen as personal trust relationships that are built from the bottom-up, it may look as though state intervention has no place in its development. Thus, Fukuyama (1995; 2000) suggests that state interference and bottom-up activism are fundamentally at odds. Much of the social capital literature views top-down central state regulation as substituting or 'crowding out' spontaneous citizen initiatives (van Oorschot et al, 2005; see also Wolfe, 1989, and Zijderveld, 1998).

Conversely, the political scientist Peter Hall (1999) has argued that British government policy has helped to stimulate citizen involvement in the voluntary sector. Good government and working institutions tend to bring about general trust (Levi, 1998; Kumlin and Rothstein, 2005). Similar findings relate to the context of social capital's influence on development outcomes: "paradoxical though it may seem, "top-down" efforts are usually needed to introduce, sustain, and institutionalize "bottom-up" development' (Uphoff cited in Woolcook, 1998: 179; see also Evans, 1996).

Clearly, there is a dispute between those who view state intervention as futile or counterproductive and those who consider it necessary in order to support citizen engagement. In an attempt to reconcile this tension, it has been argued that government input is helpful only where there is demand for certain goods or activities that citizens themselves cannot fulfil (Evans, 1996). This will be elaborated below.

\subsection{Preconditions of social capital formation}

A case can be made that the public sector can make an effort at stimulating the contacts that, in turn, promote social capital formation. The literature suggests a number of 
favourable conditions for the development of social capital. Four of them are connected with the contact situation itself:

- Role of government: Government intervention can be useful to kick-start citizen cooperation if the public sector provides those resources that are not available to the citizens (Evans, 1996: 1121). Thus, an initial governmental input is helpful. Once cooperation has been set in motion, government should hold off to avoid stifling citizen initiative.

- Local knowledge: The local knowledge of government representatives is essential (Moore, 1989). Ideally, they should be based in the region where they operate because an understanding of local problems and trusting relationships with the population are crucial.

- Common endeavour: Encounters should be tied to a common endeavour, be it 'recreational, social, service-oriented or political' (Hall, 1999: 418). This is important to give participants a topic of common interest rather than presenting the encounter as an end in itself.

- Finally, the quality of communication is important (Klein-Hitpaß et al, 2006). In other words, encounters designed to build trust should be personal and thorough. In a cross-border setting, it helps when citizens speak each other's language.

Another major question is how to broaden interpersonal trust to encompass social trust in society more generally. The main problem 'is not social capital at the level of local communities but rather "scaling up" such personal and community ties' (Evans, 1996: 1125). The literature offers a few hints on this question, too:

- First, policy should be directed at broad segments of society in order to maximise the target audience (Putnam, 2000). This means that policy initiatives should aim to reach different kinds of people and as many as possible.

- Second, since contact takes a while to bring about social trust (Evans, 1996; Hall, 1999), interaction should be repeated or take place over an extended time period in order for contacts to deepen.

- Third, policy initiatives should rise above the immediately local context and try to bridge different local communities. For example, it is helpful for contacts at the interpersonal or local level to be linked to a larger scale, such as a whole region (Fox, 1994).

An overview of the conditions that promote social capital formation indicates that attuning policy to these seven factors can maximise impact. These factors can also be used as tests of successful policy design in order to develop a theoretical model for assessing policy. The aim of what follows is to test the preconditions for social capital formation against the experiences in the Polish-German border region, which has witnessed a number of attempts to create social capital from scratch after the post-Cold War opening of the border. Before 
this is done, though, the next section shows why social capital is needed in the fragile border regions of Central and Eastern Europe in particular.

\section{BORDER REGIONS' SPECIAL NEED FOR SOCIAL CAPITAL: THE POLISH-GERMAN CASE}

This section introduces the case study: with its history of forceful boundary redrawing, expulsion and closed borders, the Polish-German border region is representative of many other regions' experiences in Central and Eastern Europe. However, recent attempts to bring borderlanders together have placed the Polish-German border region at the forefront of policy innovation.

In 1991, the Polish-German border was opened for visa-free travel. The years that followed witnessed a proliferation of cross-border organisations. Four Euroregions were founded between 1991 and 1995: Neisse-Nisa-Nysa; Spree-Neisse/Nysa-Bóbr (SNB); Pro Europa Viadrina; and Pomerania (Zdulski, 2002). ${ }^{2}$ Euroregions are voluntary associations of territorial-administrative units that straddle national boundaries (Kepka, 2004). These together make up the territory of a Euroregion, and they also select the members of joint Euroregional institutions such as a council that lays down the broad strategy or the Euroregion offices that manage the Euroregion's daily affairs. All four Polish-German Euroregions have the common goal of improving living standards in the border regions and bringing together citizens from both sides.

Regional authorities and towns alike began to cooperate across the Polish-German border after its opening. Next to cross-border development initiatives, there were also attempts to introduce joint planning and to coordinate public services (Malchus, 1992). There is a 'soft' element of cross-border cooperation that is seen as increasingly important. This refers to social relations between borderlanders and socio-cultural linkages across the border. How easy and how frequent is cross-border contact? Can and do the borderlanders trust each other? Do they speak each other's language? In short, what is at stake is 'social capital' in the shape of trusting relationships between the residents of the border region. Since the aim is to link people across the border, this would take the shape of inclusive 'bridging' social capital.

Economic and political relations in the borderlands will be affected by how the people who live on both sides of a border relate to each other. Borders in Central and Eastern Europe have a tradition of largely closed borders, aggravating a history of conflict and distrust. The Polish-German border is an emblematic case. It was the product of aggression and forceful boundary redrawing during World War II. Moreover, due to the mass expulsions of Poles and Germans, the people who found themselves living on both sides after the war had never had any experience with joint neighbourship (Urban, 2004). The border was closed to crossborder contact for most of the communist period. When it was opened in 1991, the people

\footnotetext{
${ }^{2}$ For simplicity's sake, this paper focuses on the Polish-German cross-border element. It excludes any information about the Swedish part of Euroregion Pomerania. The German-Polish-Czech Euroregion Neisse-Nisa-Nysa will be discussed only with respect to its Polish-German component.
} 
who lived on both sides of the border did not know, and were suspicious of, each other (Lisiecki, 1995).

At the same time, the Polish-German borderlands suffer from major material setbacks. There are many indicators of structural weakness. According to the cross-border operational programmes, the borderlands experience four structural problems, namely 1) economic weakness, notably the decline in heavy industry and resulting unemployment, 2) insufficient cross-border infrastructure, 3) environmental pollution, and 4) on the German side, population decline largely due to migration. Perhaps most importantly, the border coincides with a steep welfare gap: even though Germany's poorest regions border on Poland's wealthiest, the German side is still much more prosperous than the Polish (Bertram, 1998). Against this bleak outlook, a host of studies have argued that such a region has few development chances (Krätke, 1998; 1999; Guz-Vetter, 2002). There is a danger that much-needed development capital may continue to skip the borderlands to do business in the large cities (Guz-Vetter, 2002).

As most of these problems affect both sides of the border equally, they can only be solved jointly, especially as regards attracting development capital and stimulating growth. Crossborder cooperation between local firms is needed but not always easy to achieve: "Relationships of trust are essential to "high quality" cooperation and interfirm networks seem to develop more easily in regions where the economic and social actors have a common sociocultural background' (Krätke, 2002: 139). In this view, social capital is seen to precede economic development and is just as important as a region's economic or institutional make-up in stimulating cooperation (Krätke, 1998).

Among local entrepreneurs in the Polish-German border region, there has so far not been a lot of demand for cross-border initiatives. It has been suggested that this lack of regional thinking is symptomatic of a more widespread apathy. Ordinary citizens do not seem keen on stronger cross-border linkages, and relations between Poles and Germans are shaped by stereotypes and prejudices (Lisiecki, 1995; Matthiesen, 2002). The fact that the PolishGerman region is a 'low-trust environment' tends to hold back any much-needed crossborder cooperation between small local firms (Krätke, 1999: 632; see also Krätke, 2002; Guz-Vetter, 2002). In other words, the region finds itself in a vicious circle in that concerted regional cooperation would be necessary to activate the region and improve both sides' well-being. However, mutual suspicions inhibit such cooperation.

While a low trust environment may hamper economic development, there is another reason why social capital is necessary. It relates to the effectiveness of cross-border governance. Popular support is a precondition for efficient cross-border governance (Matthiesen, 2002). Joint problem solving can produce economies of scale between the cooperating local and regional authorities in such fields as spatial planning, infrastructure development or environmental protection (Scherhag, 2008). However, such synergies require a minimum of trust among the border populations:

'In the end, it is the population's support, acceptance and interests that determine the success of cross-border cooperation. As long as views of the 
neighbour are shaped by negative stereotypes and prejudices, the 'border in the head' will persist.' (Scherhag, 2008: 30). ${ }^{3}$

Robert Knippschild (2008: 73) describes a hypothetical scenario in which cooperation is, in fact, the optimum solution for everybody. However, citizens' willingness to use infrastructure on the other side are a precondition for this success: shared facilities such as binational kindergartens, jointly used hospitals or recreational facilities will only be successful if they are accepted and used by the border region residents (Matthiesen, 2002; Knippschild, 2008).

To summarise, the Polish-German border region is in an economically extremely difficult position, not least due to the mutual suspicions among borderlanders. There is an urgent need to improve citizen relations across the border and to try and foster social capital that can bridge the border. The next section will describe an important effort to do just this.

\section{THE SMALL PROJ ECTS FUND IN THE POLISH-GERMAN BORDER REGION}

The European Union's Community Initiative INTERREG has been the main funding instrument for cross-border cooperation in Europe since its introduction in 1990 (Perkmann, 2003). It was introduced in 1990 and it has provided somewhere around $€ 11.5$ billion to cross-border programmes at different borders since then. ${ }^{4}$ INTERREG money can only be spent on the territory of EU member states. Prior to their accession in 2004 (2007 in the case of Bulgaria and Romania), the Central and Eastern European member states received money from the mirror fund Phare CBC. In the 2007-2013 funding period, INTERREG has been upgraded to become one of the key objectives of cohesion policy, European Territorial Cooperation or Objective 3, worth $€ 7.8$ billion.

Crucially, there is an element in this that attempts to engage the people who live on both sides of the border: the small projects fund. To speak of one 'small projects fund' is slightly misleading because the European Union does not itself set aside a share of its crossborder funds for small projects. However, the programme managers at the different borders have the option of setting up a small projects fund for so-called 'people-to-people' projects such as sports festivals or meetings between clubs from both sides of the border. Small projects usually feature simpler application procedures than more expensive projects. They are dedicated to the specific purpose of bringing people from both sides together in a meaningful setting. The aim is for borderlanders to get to know the neighbours from the other side of the border, to start trusting them, build friendly connections with the other side and generally to improve good neighbourly relations in the region. Projects take place in the areas of culture and sport, tourism or youth exchanges.

\footnotetext{
${ }^{3}$ All translations into English are the author's.

${ }^{4}$ Own estimate from various sources.
} 


\subsection{History}

The concept of a small projects fund originated in the Polish-German border region as part of the INTERREG II-Phare CBC programme (Zdulski, 2002). In 1995, there was a conviction that measures were needed to foster contacts and therefore trust between the citizens of both sides (Interviews PL4 and DE3). However, under the Phare CBC regulations, projects had to be worth at least $€ 2$ million. This was seen as too much for the purposes of peopleto-people projects. Thus, the local administrations on the Polish side set aside between two and $€ 3$ million per year for small projects, (Jałowiecki and Smętkowski, 2004). INTERREG money was made available on the German side. The small projects funds were managed in the Euroregion offices themselves. Projects could be supported with as much as $€ 50,000$, up to 75 per cent of the total project cost (IRC et al, 2006).

An evaluation of the Polish-German cross-border programme describes the small projects fund as one of the programme's successes, 'convincing the European Commission of the usefulness of this solution. The Polish innovation was popularized and effectively implemented in other cross-border co-operation programmes in the entire European Union' (IRC et al, 2006: 9). Indeed, introducing small projects funds as part of cross-border programmes, though not obligatory, is encouraged. The possibility was mentioned in the Phare $C B C$ regulations and it is mentioned again in the INTERREG guidelines, even though INTERREG never stipulated any minimum cost of a project, as Phare CBC had done. Thus:

'...measures covering this type of cooperation are eligible, especially the creation of funds with limited resources (micro project facility) to implement small projects promoting cross-border integration of local populations (people-to-people actions) whose management could be [devolved] directly to the programme Secretariat, crossborder initiatives (e.g. Euroregions) or specific Steering Committees.' (DG Regio, 2003).

\subsection{Management and implementation}

Arrangements regarding small projects funds vary between different programmes across the EU. The programmes' monitoring committees decide on the financial resources of the small projects fund, the maximum value of eligible projects, and aid ceilings. It is difficult to paint an exact picture of the fund in 52 different programmes across the EU. In general, though, it seems that small projects funds are more common in Central and Eastern European programmes which had received Phare CBC funding until their EU accession.

Despite joint programmes, committees and implementation documents, each side usually receives its own money from the programme. In the Polish-German border region, this money flows to the Regional Development Ministry in Warsaw and to the three easternmost German Länder Mecklenburg-Vorpommern, Brandenburg and Saxony. The four small projects funds, too, are often called 'joint small projects funds' but in reality, German project organisers receive German money and Polish project organisers receive Polish money.

In contrast to regular - or large - projects, the small projects fund often benefits from simplified application procedures. Its administration is devolved to a very large extent to 
the Euroregion offices. The German offices normally deal with German applications and the Polish ones with Polish applications. In the 2007-2013 funding period, Euroregion Pomerania will be the exception to this rule: it created a joint office for the small projects fund on the Polish side in Szczecin where all applications will be submitted, but there are still two separate funds.

The Euroregion offices have special staff to deal with the small projects fund. They advise applicants and help them in the application process, accept applications, assess their formal correctness and consider their content (Zdulski, 2002). Finally, local steering committees bring both sides of the Euroregion together to decide jointly whether or not a project will be funded. It usually takes only two or three months between initial application and approval. Once a funding decision is made, the project can go ahead. The project organiser must finance the project in advance. The Euroregions conduct the financial monitoring and occasional on-site checks, they help the project organisers with the write-up of the final report and, finally, they reimburse the project organiser's expenses according to the relevant aid rate. Projects can last up to a year but most take only two to seven days.

There is an open, standing call for applications but, in general, there does not seem to be much publicity about the possibility of conducting a project (Interview DE8). Numerous project organisers undertake projects fairly regularly and are familiar with the rules. Others hear about funding opportunities through informal channels. Only non-profit public bodies are eligible to apply for a project. These include municipalities, NGOs, chambers of commerce and other public organisations. Applicants must be based in the Euroregions, which is also where the project must take place. They must have a partner from the other side. Finally, projects must be joint insofar as they must carry out at least two of the following tasks jointly: preparation and planning, implementation, financing or employing personnel from both sides.

\subsection{The projects: numbers, cost and content}

Table 1 characterises the small projects funds in the four Polish-German Euroregions for the 2000-2006 funding period. It focuses on INTERREG and does not take into account Phare $\mathrm{CBC}$ so that the numbers shown for the Polish sides are for three, rather than seven, years. The table shows that the overall INTERREG contribution of $€ 10.4$ million was modest - but that as many as 2,787 small projects were funded. This amounts to an average of 140 per year or two to three projects per week in each Euroregion. 
Table 1: Number and cost of INTERREG IIIA-funded small projects 2000-2006 (20042006 for the Polish side)

\begin{tabular}{|c|c|c|c|c|}
\hline & Side & $\begin{array}{l}\text { No. of } \\
\text { projects }\end{array}$ & $\begin{array}{c}\text { No. of projects } \\
\text { p.a. }\end{array}$ & $\begin{array}{l}\text { Total INTERREG } \\
\text { contribution (€) }\end{array}$ \\
\hline \multirow[t]{2}{*}{ Pomerania } & German & 717 & 102 & $1,285,891$ \\
\hline & Polish & 230 & 77 & $1,959,065$ \\
\hline \multirow{2}{*}{$\begin{array}{c}\text { Pro Europa } \\
\text { Viadrina }\end{array}$} & German & 527 & 75 & $1,299,262$ \\
\hline & Polish & 210 & 70 & $1,040,445$ \\
\hline \multirow[t]{2}{*}{ SNB } & German & 547 & 78 & $1,422,574$ \\
\hline & Polish & 255 & 85 & 992,381 \\
\hline \multirow[t]{2}{*}{ Neisse-Nysa } & German & 150 & 21 & $1,232,998$ \\
\hline & Polish & 151 & 50 & $1,183,541$ \\
\hline TOTAL & & 2,787 & & $10,416,157$ \\
\hline
\end{tabular}

Notes: Polish INTERREG IIIA-contributions were converted into Euros using 2009 prices. The aid rate covers the INTERREG contribution only. It could be increased using national funds.

Sources: Email communication with the Euroregion offices; Euroregion Pro Europa Viadrina (2008); Euroregion Spree-Neisse/Nysa-Bóbr (2008).

Table 2 shows that the aid ceilings and maximum costs changed slightly with the new funding period. In Euroregion Neisse-Nisa-Nysa, the maximum project cost was lowered from $€ 20,000$ to $€ 15,000$; in all other Euroregions, it was increased. With the exception of Euroregion Pomerania, there seems to be an emerging consensus that the ideal maximum project cost lies somewhere near $€ 15,000$. The aid ceiling was increased to 85 per cent, giving project organisers a larger contribution towards their costs. 
Table 2: Changes in maximum project costs and aid rates in the new funding period

\begin{tabular}{|c|c|c|c|c|}
\hline & $\begin{array}{c}\text { Maximum } \\
\text { project cost }(\boldsymbol{\epsilon}) \\
\mathbf{2 0 0 0 - 2 0 0 6}\end{array}$ & $\begin{array}{c}\text { Maximum aid rate } \\
\mathbf{2 0 0 0 - 2 0 0 6}\end{array}$ & $\begin{array}{c}\text { Maximum } \\
\text { project cost }(\boldsymbol{\epsilon}) \\
\mathbf{2 0 0 7 - 2 0 1 3}\end{array}$ & $\begin{array}{c}\text { Maximum aid } \\
\text { rate 2007-2013 }\end{array}$ \\
\hline Pomerania & 5,000 & $75 \%$ & 25,000 & $85 \%$ \\
\hline PEV & 15,000 & $75 \%$ & 17,647 & $85 \%$ \\
\hline SNB & 15,000 & $75 \%$ & 17,647 & $85 \%$ \\
\hline Neisse-Nysa & 20,000 & $75 \%$ & 15,000 & $85 \%$ \\
\hline
\end{tabular}

Note: The aid rate covers the Objective 3 contribution only. On the Polish side, it can be increased by another $10 \%$ using national funds.

Source: Euroregions' own documentation.

Usually, projects should attract Poles and Germans in equal shares. It is difficult to estimate how many participants were reached in the past funding period. The number of direct participants can be anywhere between 15 and 1,000, but normally lies between 20 and 100. For some public projects, the number of indirect participants - people who attend a picnic or sports festivals - can reach several thousand. The number of direct and indirect participants in small projects in the past funding period can be estimated at 150,000300,000 . Out of a total border regional population of around 4.3 million, this is a considerable share for a policy intervention aimed at individual citizens.

Figure 1 shows projects from the 2000-2006 period that were organised on the Polish side of Euroregion SNB according to theme. The figure shows that culture was by far the most frequent theme: 111 projects in this category amount to 44 per cent. Culture is followed by tourism, sport and youth projects. In many of the other Euroregions, youth projects tend to be much more prominent than this (Interview PL1; Jałowiecki and Smętkowski, 2004). Social matters and vocational projects in the areas of education and economy were much rarer. Ten projects in the areas of environment and health amounted to only four per cent. 
Figure 1: Small projects by theme in Euroregion SNB 2000-2006

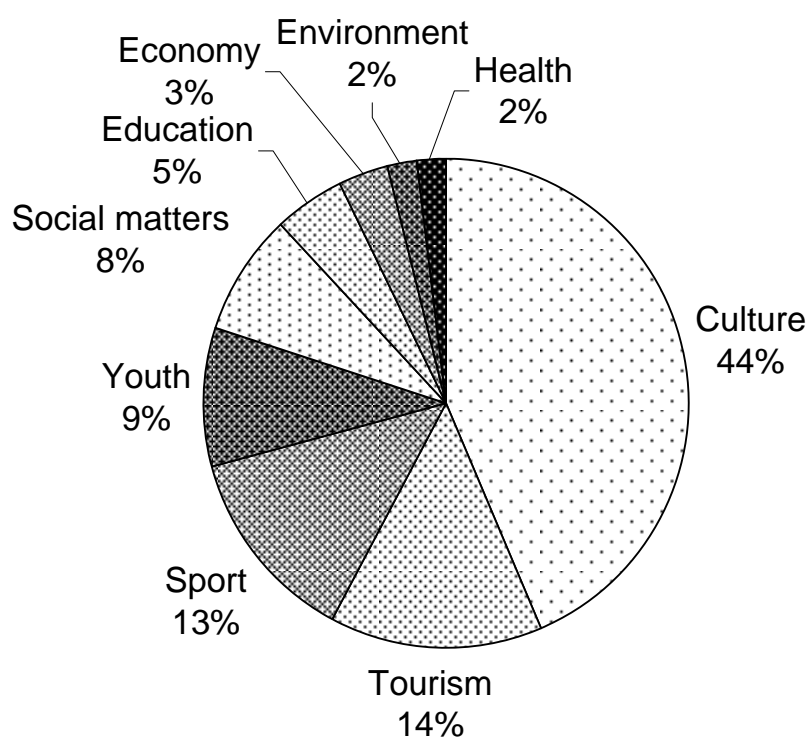

Source: Euroregion Spree-Neisse/Nysa-Bóbr (2008)

Some projects are used to fund conferences or publications, but the majority appear to be genuine 'people-to-people' projects. For example, many projects involve sporting competitions such as the 'Europe Marathon 2005/06' in the Polish-German twin town Görlitz-Zgorzelec or a 2007 angling competition in the Polish town Kłodawa. Other examples include a vintage car exhibition in Euroregion Pro Europa Viadrina that took place in 2007. 2,000 visitors who were interested in vintage cars, old fire trucks, or military vehicles of formerly hostile armies attended the exhibition (Euroregion Pro Europa Viadrina, 2008). One might also mention a youth theatre that allowed Polish, German and Czech teenagers to explore local legends from Euroregion Neisse-Nisa-Nysa. As part of the project, they learned how to communicate in spite of the triple language barrier. The play's success led to longer-term cooperation within the theatre group and to plans to broaden the membership (Euroregion Neisse-Nisa-Nysa, n.d.). As a one-day event, a PolishGerman culinary fair took place in December 2006 in the Polish town Świebodzin: Poles and Germans from two neighbouring districts attended to taste regional specialties and admire regional handicrafts, while local musicians played Christmas songs (Euroregion SpreeNeisse/Nysa-Bóbr, 2008). These events offer a variety of sites for borderlanders to meet and communicate.

\section{CONDITIONS OF SOCIAL CAPITAL FORMATION IN THE POLISH-GERMAN BORDER REGION}

Project organisers have argued that participants' opinions of the neighbours improve during the course of a project (Jałowiecki and Smętkowski, 2004), although one should add that project organisers have an incentive to present the effects of a project in the most favourable terms possible. Taking a more rigorous approach to evaluating the small projects 
fund, this section maps its characteristics onto the conditions for the development of social capital that were developed in the first section.

As far as the role of government is concerned, the literature suggests that an initial government input can be beneficial but that governments should show restraint once cooperation has been initiated. The history and implementation of the small projects fund indicate that it fulfils this condition. As mentioned earlier, in 1995, Polish local authorities were interested in organising inexpensive people-to-people projects but the Phare CBC regulations prevented this. In response, Polish and German national and regional authorities created the small projects fund which has been running the same way ever since: the programme managers at the national and regional level set aside a certain amount of money and they leave implementation largely to the Euroregions. In general, the small projects fund is less bureaucratic, closer to the ground and more easily implemented than large projects (IfS, 2003).

The second condition concerns the local knowledge of government representatives. In this respect, the devolved implementation structures of the small projects fund are a real asset. Special members of staff in the Euroregional offices help local initiators such as clubs or municipalities with the preparation of projects. These project organisers themselves, such as the angling clubs of the towns Ktodawa and Seelow, are based in the territory of the Euroregion, where they also have their own membership. They are in an excellent position to organise projects in their area of interest and expertise.

The third condition stipulates that cross-border contact be tied to a common endeavour. By their nature, small projects are linked to a common theme such as angling or vintage cars. Figure 1 has shown, using the example of Euroregion SNB, that there is quite a broad range of themes, though most fall into the area of culture and youth. Projects use a common interest as a starting point and project organisers recruit the direct participants from their membership. In other words, the participants of these projects share a pre-existing interest that offers a suitable topic for cross-border exchanges.

The quality of communication is another key condition of successful cross-border encounters. The small project setting promotes intensive, face-to-face contact between the participants, and they meet on an equal footing. Such a setting is conducive to communication. It will most likely not reproduce any old stereotypes but rather explode them (Lisiecki, 1995). However, the quality of communication is no doubt hindered by the limited language skills among borderlanders. According to one German interviewee, 'if Poles did not speak German relatively well, many things would be even more difficult. Over there, the willingness to learn German is much stronger than here' (Interview DE7; also PL1). Moreover, interviewees argue that project participants should be encouraged to interact at all stages of the project (Interviews DE7 and DE8). However, it is not always clear that this is the case. One interviewee argued that not all projects are successful in bringing people together:

'You often find this division, where a project organiser attached little importance to this - perhaps because he is not sensitive enough. Then Poles are among themselves and Germans are among themselves ... But where people are sensitive 
and have tried to prevent this, by playing guitar around the camp fire, people come together in the end. And they do end up talking to each other.' (Interview DE8).

Thus, Polish-German projects vary as regards the quality of communication. In general, there are ways to maximise high-quality communication, but the language barrier poses a considerable structural obstacle.

A second set of conditions relates to the scaling-up of interpersonal trust to broader relationships of trust and social capital in the region. This is important because it is entirely possible for a Pole to be good friends with a German, whilst hating and distrusting all Germans' (Interview PL3). In some respects, this might be difficult to achieve through the small projects fund because knowledge about this fund among potential applicants cannot be taken for granted. As we have seen, applicants are often specialised organisations that operate in their field. They already know about the about existing funding opportunities and some organise projects regularly. However, there is no single source of information or publicity to inform potential new applicants. The wider public certainly do not seem to know a lot about the Euroregions themselves, let alone the small projects fund (Strüver, 2004; Häkli, 2004).

One of the conditions for scaling-up is that projects reach many people and different segments of society. Several hundred thousand participants in small projects suggest that these do indeed reach a wide audience. The rule that there should be a roughly equal number of Polish and German participants prevents any obvious imbalances. The recent convergence between the four Euroregions on similar levels of funding suggests that a equilibrium has been found, allowing a large number of projects to be funded but still providing enough funding to organise a successful project. The many different areas in which projects are organised would suggest that they appeal to many different people. Nevertheless, as the previous section has also shown, there is a heavy reliance on cultural projects. Many citizens might find some cultural themes such as artistic photo exhibitions uninteresting or difficult to access.

The second condition for scaling-up stipulates that encounters should either cover an extended period of time or to be repeated in order to have a lasting effect. As we have seen, projects vary in length, which can range from one day to a whole year. However, they normally take no longer than a week, which seems too short to engage participants' interest beyond the project. Still, projects can be repeated several times with declining aid rates over time and this is done frequently (Interviews PL5 and PL7). Moreover, projects are not intended to be one-off events. According to the rules, they should strengthen partnership permanently. For example, an association could be extended as was the case with the Polish-German-Czech theatre group. When asked about the long-term effect of projects, one interviewee declared: 'We have made the experience that the majority of the projects that we realise are not one-off projects. They really have their continuation.' (Interview PL7).

And finally, social capital is more likely to grow if there is a broader effect that links local encounters to a larger framework, such as the regional or the local context. Small projects 
seem to achieve this to some extent. Many of them have a local reference framework. For example, local fare was presented at the Polish-German culinary fair in Świebodzin, while the theatre group in Euroregion Neisse-Nisa-Nysa explored local legends. At the same time, 'local' traditions have a very different meaning in the Polish-German borderlands than elsewhere in Western Europe. As mentioned at the outset, Polish-German neighbourship is still very young in this region. On the Polish side in particular, the population has only been settled in the region for sixty years. While people can take root in this time, few regional traditions originate in the borderlands and there are even fewer shared traditions across the Polish-German border. In this sense, small projects cannot merely draw on local traditions; to some extent, they have to contribute towards building them.

\section{CONCLUSION}

The small projects fund is an example of government trying explicitly to stimulate social capital. This paper has provided an initial appraisal of these attempts. It had to confine itself to examining the fund in the light of seven conditions. Much of this analysis suggests that small projects are suited to promote trust between individuals. However, the picture is less clear as far as the conditions for scaling-up are concerned. Thus, it is not certain that individual trust is subsequently translated into broader social capital for the region.

Regional policy makers were equally enthusiastic about the fund in 2009 as they had been in 2005. There is broad agreement that the small projects fund is making a positive contribution. Still, one interviewee criticised the lack of evidence on which to base this claim:

'It is known that the more contacts, relations and joint events we organise, the stronger the awareness of the shared border should be, at least in theory. Still, we do not have the research tools to assess this question. In order to assess it, some sociological studies should be carried. Can one imagine a situation without the fund and without these projects? We have no grounds for comparison.' (Interview PL6).

Ultimately, policy outputs must be measured against policy aims. Designed to bring about changes in attitudes, the fund seems to lend itself to a new approach to policy evaluation that observes change over time. To be sure, attitude change is a very gradual process. One cannot expect participants' opinions to change from suspicion to affection over the course of a project. Rather, contacts are initiated where previously there were none, old acquaintances are reinforced and negative stereotypes are eliminated little by little (Interviews PL5 and DE8). An examination of these dynamics could not only isolate the impact of the policy intervention. It could also shed more light than before on the reasons for social capital formation by analysing the conditions that have been outlined in this paper and that vary between projects - such as a project's length or the intensity of the encounter.

The small projects fund must be seen in the context of a steady flow of cross-border activity (Interviews DE1; DE2; PL2 and PL5). Traffic across the border increased massively in 
the first few years after the border was opened (Bort, 1998) and again after Poland's accession to the Schengen area of passport-free travel in December 2007. Much of it remains in the borderlands. Many people cross the border for mundane tasks such as shopping, fuelling their car or to get a haircut. Others have family or friends on the other side. However, the most concerted efforts to bring Poles and Germans together have been organised through the small projects fund, and there is a strong demand for these projects (Interview DE4). The many face-to-face encounters that these projects have made possible render the fund one of the most important instruments, if not the most important instrument, to promote cross-border understanding.

At the same time, other policy interventions that also have an impact on cross-border citizen relations are more difficult to contextualise. For example, many large INTERREG projects have important side-effects on exchanges between Poles and Germans. This is especially true for infrastructure projects, although, in general, developing the crossborder infrastructure does not seem to be a priority: more than fifteen years after the border was opened, there was still an urgent lack of border crossings. Furthermore, Germany was one of the many West European countries that excluded Central and Eastern Europeans from their labour markets after the EU enlargements of 2004 and 2007. Poles will not be able to work in Germany until 2011. This clearly has important implications for citizen relations. It may soothe some German fears of Polish competition but it also hinders cross-border commuting and exchanges in the workplace. This shows that many policy initiatives with a cross-border impact are not always coordinated and can sometimes work in opposite directions. It remains to be seen whether small project support can improve citizen relations and deliver social capital in the Polish-German border region. 


\section{BIBLIOGRAPHY}

Primary sources:

DG Regio, European Commission (2003) A practical guide for preparing new, and amending existing, INTERREG III Community Initiative Programmes as a result of Enlargement, available online

at <http://ec.europa.eu/regional_policy/interreg3/documents/practical_guide_for_interr eg_14_3_03_en.pdf> (accessed June 2009)

Euroregion Neisse-Nisa-Nysa (n.d.) Kleinprojekte INTERREG IIIA 2001-2003/Fond malých projektů INTERREG IIIA 2001-2003/Mate projekty Interreg IIIA 2001-2003, Zittau, Kommunalgemeinschaft Euroregion Neisse e.V.

Euroregion Pro Europa Viadrina (2008) Raport z funduszu mikroprojektów w ramach Inicjatywy Wspólnotowej INTERREG IIIA/Von Mensch zu Mensch, Projekte im Rahmen des Small Project Fund INTERREG IIIA, Gorzów Wlkp./Frankfurt (Oder), Euroregion Pro Europa Viadrina

Euroregion Spree-Neisse/Nysa-Bóbr (2008) Fundusz mikroprojektów w Euroregionie „Sprewa-Nysa-Bóbr”/,Spree-Neisse-Bober” w ramach inicjatywy wspólnotowej INTERREG IIIA, Gubin, Euroregion Euroregion Spree-Neisse

IfS (2003) Halbzeitbewertung zur Gemeinschaftsinitiative Interreg III A im Freistaat Sachsen Los 2: Programm Freistaat Sachsen - Woiwodschaft Niederschlesien 2000 2006, Endbericht im Auftrag der Sächsischen Staatskanzlei

IRC, EUROREG and Price Waterhouse Coopers (2006) An ex post evaluation of the Phare Cross-Border Co-operation Programme Poland-Germany 1999-2001, Report summary.

Academic literature:

Anderson, M. (1996) Frontiers: Territory and State Formation in the Modern World, Oxford, Polity Press

Batt, J. and Wolczuk, K. (2002) (eds.) Region, State and Identity in Central and Eastern Europe, London, Frank Cass

Bertram, H. (1998) 'Double transformation at the eastern border of the EU: the case of the Euroregion Pro Europa Viadrina', GeoJournal, 44:3, 215-24

Blatter, J. (1997) 'Examining Crossborder Cooperation: A Border-Focused and BorderExternal Approach', Journal of Borderlands Studies, 12:1/2, 151-74

Boix, C. and Posner, D.N. (1998) 'Social Capital: Explaining Its Origins and Effects on Government Performance', British Journal of Political Science, 28:4, 686-93 
Bort, E. (1998) 'Mitteleuropa: The Difficult Frontier', in M. Anderson and E. Bort (eds.) The Frontiers of Europe, London, Pinter, 91-108

Coleman, J.S. (1988) 'Social Capital in the Creation of Human Capital', American Journal of Sociology, 94, s95-s120

Durlauf, S.N. (1999) 'The Case “Against” Social Capital, Focus, 20:3, 1-5

Evans, P. (1996) Government Action, social capital and development, World Development $24: 6,1119-32$

Fine, B. (1999) 'The Developmental State is Dead - Long Live Social Capital?', Development and Change, 30:1, 1-19

Foley, M.W. and Edwards, B. (1999) 'Is It Time to Disinvest in Social Capital?', Journal of Public Policy, 19:2, 141-73

Fox, J.A. (1994) 'The Difficult Transition from Clientelism to Citizenship: Lessons from Mexico', World Politics, 46:2, 151-84

Fukuyama, F. (1995) Trust: The Social Virtues and the Creation of Prosperity, London, Hamish Hamilton

Grix, J. and Knowles, V. (2002) 'The Euroregion as a Social Capital Maximizer: The GermanPolish Euroregion Pro-Europa Viadrina’, Regional and Federal Studies 12:4, 154-76

Guz-Vetter, M. (2002) Polsko-niemieckie pogranicze: Szanse i zagrożenia w perspektywie przystapienia Polski do Unii Europejskiej, Warsaw, Instytut Spraw Publicznych

Häkli, J. (2004) 'Governing the mountains: Cross-border Regionalization in Catalonia', in 0. Kramsch and B. Hooper (eds.) Cross-Border Governance in the European Union, London, Routledge, 56-69

Hall, P.A. (1999) 'Social Capital in Britain', British Journal of Political Science, 29:3, 417-67

Jałowiecki, B. and Smętkowski, M. (2004) Małe projekty Euroregionalne, in G. Gorzelak, J. Bachtler and M. Kasprzyka (eds.) Wspótpraca Transgraniczna Unii Europejskiej: Doświadczenia Polsko-Niemieckie, Warsaw, Wydawnictwo Naukowe „Scholar”

Kennard, A. (2004) 'Cross-border governance at the future eastern edges of the EU: A regeneration project?', in 0 . Kramsch and B. Hooper (eds.) Cross-border governance in the European Union, London, Routledge, 107-20

Kepka, J.M.M. (2004) 'The Nysa Euroregion: The First Ten Years', Eurasian Geography and Economics, 45:3, 162-89

Klein-Hitpaß, K., Leibenath, M. and Knippschild, R. (2006) 'Vertrauen in grenzüberschreitenden Akteursnetzwerken: Erkenntnisse aus dem deutsch-polnischtschechischen Kooperationsprojekt ENLARGE-NET', disP, 164:1, 1-22 
Knippschild, R. (2008) Grenzüberschreitende Kooperation: Gestaltung und Management von Kooperationsprozessen in der Raumentwicklung im deutsch-polnisch-tschechischen Grenzraum, IÖR-Schriften, 48

Krätke, S. (1998) 'Problems of Cross-border Regional Integration: The Case of the GermanPolish Border Region', European Urban and Regional Studies, 5:3, 249-62

Krätke, S. (1999) 'Regional Integration or Fragmentation?' The German-Polish Border Region in a New Europe', Regional Studies, 33: 7, 631-41

Krätke, S. (2002) 'Cross-Border Cooperation and Regional Development in the GermanPolish Border Area' in M. Perkmann and N.-L. Sum (eds.) Globalization, Regionalization and Cross-Border Regions, Houndmills, Palgrave Macmillan, 125-47

Kumlin, S. and Rothstein, B. (2005) 'Making and breaking social capital: The Impact of Welfare-State Institutions', Comparative Political Studies, 38:4, 339-65

Levi, M. (1996) 'Social and Unsocial Capital: A Review Essay of Robert Putnam's Making Democracy Work’, Politics \& Society, 24:1, 45-55

Levi, M. (1998) 'A State of Trust', in V. Braithwaite and M. Levi (eds.) Trust and Governance, New York, Russell Sage Foundation, 77-101

Lisiecki, S. (ed.) (1995) Otwarta granica: Raport z badań na pograniczu polsko-niemieckim 1991-1993, Poznań, Instytut Zachodni

Malchus, V. Frhr. Von (1992) 'Deutsch-polnische grenzübergreifende Zusammenarbeit: Erste Überlegungen und Folgerungen', Grenzübergreifende Raumplanung: Erfahrungen und Perspektiven der Zusammenarbeit mit den Nachbaarstaaten Deutschlands, Forschungsund Sitzungsberichte der ARL, 190, 160-73

Matthiesen, U. (2002) 'Die Osterweiterung der Europäischen Union und die deutschpolnische Grenzregion - Problemlagen und Lernchancen', IRS Aktuell 34, 1-5

Moore, M. (1989) 'The Fruits and Fallacies of Neoliberalism: The Case of Irrigation', World Development, 17:11, 1733-50

O'Dowd, L. (2002) 'The Changing Significance of European Borders', in Regional and Federal Studies, 12:4, pp. 13-36

Perkmann, M. (1999) 'Building governance institutions across European borders', Regional Studies 33:7, 657-67

Perkmann, M. (2003) 'Cross-border regions in Europe: Significance and drivers of regional cross-border co-operation', European Urban and Regional Studies, 10:2, 153-71

Portes, A. (1998) 'Social Capital: Its Origins and Applications in Modern Sociology', Annual Review of Sociology, 24: 1-24 
Putnam, R.D. (2000) Bowling Alone: The Collapse and Revival of American Community, New York, Touchstone

Putnam, R.D. with Leonardi, R. and Nanetti, R.Y. (1993) Making Democracy Work: Civic traditions in Modern Italy, Princeton, Princeton University Press

Scherhag, D. (2008) Europäische Grenzraumforschung, Hannover, Akademie für Raumforschung und Landesplanung

Scott, J. (2002) 'Cross-border Governance in the Baltic Sea Region', Regional and Federal Studies, 12:4, 135-53

Strüver, A. (2004) '“We are only allowed to re-act, not to act”: Eurocrats' strategies and borderlanders' tactics in a Dutch-German cross-border region', in O. Kramsch and B. Hooper (eds.) Cross-Border Governance in the European Union, London, Routledge, 2540

Szabo, G. and Koncz, G. (2006) 'Transboundary Interaction in the Hungarian-Romanian Border Region: A Local View' in J.W. Scott (ed.) EU Enlargement, Region Building and Shifting Borders of Inclusion and Exclusion, Aldershot, Ashgate

Urban, T. (2004) Der Verlust: Die Vertreibung der Deutschen und Polen im 20. Jahrhundert, Munich, C.H. Beck

Uslaner, E.M. (2003) 'Trust, Democracy and Governance: Can Government Policies Influence Generalized Trust?', in M. Hooghe and D. Stolle (eds.) Generating Social Capital: Civil Society and Institutions in Comparative Perspective, Basingstoke, Palgrave Macmillan

van Oorschot, W., Arts, W. and Halman, L. (2005) 'Welfare state effects on social capital and informal solidarity in the European Union: evidence from the 1999/2000 European Values Study', Policy \& Politics, 33:1, 33-54

Whiteley, P. (2000) 'Economic Growth and Social Capital', Political Studies, 48:3, 443-66

Woolcock, M. (1998) 'Social capital and economic development: Towards a theoretical synthesis and policy framework', Theory and Society, 27:2, 151-208

Yoder, J.A. (2003) 'Bridging the European Union and Eastern Europe: Cross-border Cooperation and the Euroregions', Regional and Federal Studies, 13:3, 90-106

Zdulski, M. (2002) Polish Experience in Cross-border Cooperation, Jelenia Góra, Stowarzyszenie Gmin Polskich Euroregionu Nysa

Zich, F. (1998) 'Germany and the Germans in the Attitudes of People Living on the CzechGerman Border', Czech Sociological Review, 6:2, 241-59

Zijderveld, A.C. (1998) 'The vertical division of the European welfare state', Society 35:4, 62-71 